\title{
Mouse Rad 1 deletion enhances susceptibility for skin tumor development
}

\author{
Lu Han+2, Zhishang Hü22, Yuheng Liu², Xiangyuan Wang33,4,5, Kevin M Hopkins ${ }^{7}$, Howard B Lieberman,8 and \\ Haiying Hang*1,2
}

\begin{abstract}
Background: Cells are constantly exposed to stresses from cellular metabolites as well as environmental genotoxins. DNA damage caused by these genotoxins can be efficiently fixed by DNA repair in cooperation with cell cycle checkpoints. Unrepaired DNA lesions can lead to cell death, gene mutation and cancer. The Rad1 protein, evolutionarily conserved from yeast to humans, exists in cells as monomer as well as a component in the 9-1-1 protein complex. Rad1 plays crucial roles in DNA repair and cell cycle checkpoint control, but its contribution to carcinogenesis is unknown.

Results: To address this question, we constructed mice with a deletion of Mrad1. Matings between heterozygous Mrad1 mutant mice produced Mrad1+/+ and Mrad1+/-but no Mrad1-/- progeny, suggesting the Mrad1 null is embryonic lethal. Mrad1+/-mice demonstrated no overt abnormalities up to one and half years of age. DMBA-TPA combinational treatment was used to induce tumors on mouse skin. Tumors were larger, more numerous, and appeared earlier on the skin of $\mathrm{Mrad}^{+/-}$mice compared to $\mathrm{Mrad}^{+/++}$animals. Keratinocytes isolated from $\mathrm{Mrad1}^{+/-}$mice had significantly more spontaneous DNA double strand breaks, proliferated slower and had slightly enhanced spontaneous apoptosis than Mrad $1+++$ control cells.

Conclusion: These data suggest that Mrad 1 is important for preventing tumor development, probably through maintaining genomic integrity. The effects of heterozygous deletion of Mrad1 on proliferation and apoptosis of keratinocytes is different from those resulted from Mrad9 heterozygous deletion (from our previous study), suggesting that Mrad1 also functions independent of Mrad9 besides its role in the Mrad9-Mrad1-Mhus1 complex in mouse cells.
\end{abstract}

\section{Background}

Living organisms are continuously exposed to both physiological and environmental DNA-damaging agents. Eukaryotic cells have developed exquisite mechanisms that monitor and coordinate cell cycle progression with repair of DNA damage to maintain genome integrity. Mutations in genes that play roles in cell cycle checkpoint control and DNA repair are often associated with tumorigenesis [1,2]. Rad9, Rad1 and Hus1 are a group of genes conserved from yeast to human that play key roles in cell cycle checkpoints and DNA repair [3-8]. Their protein products form a heterotrimeric ring-like complex, called 9-1-1 [9-11]. It is believed that this complex is important

\footnotetext{
* Correspondence: hh91@ibp.ac.cn

1 National Laboratory of Biomacromolecules, Institute of Biophysics, Chinese Academy of Sciences, 15 Road Datun, Beijing 100101, China + Contributed equally

Full list of author information is available at the end of the article
}

for the function of these three proteins in DNA repair as well as activation of cell cycle checkpoints. It is not clear whether Rad1, Rad9 and Hus1 also have distinct functional activities independent of the heterotrimeric form. The S. cerevisiae checkpoint protein Rad17, the orthologue of human Rad1, forms a homocomplex in response to treatment with DNA damaging agents, and the complex is required for yeast survival after exposure to genotoxic agents [12]. Besides the existence of 9-1-1 heterotrimer in $\mathrm{K} 562$ and 293 human cells, a significant amount of hRad1 also exists in monomeric form, but monomeric hRad9 and hHus1 were not detectable in a study by Karnitz's group [10] and in our unpublished experiments in 293 human cells. These data suggest a possibility that Rad1 in humans and mice might have distinct functions independent of the 9-1-1 heterotrimer. 
Increased expression of Rad9 was found in lung, breast and prostate tumors, relative to normal corresponding tissues [13-16]. High level of Hus1 expression correlates with poor prognosis for ovarian tumors [17]. Knockdown of Rad9 in prostate tumor cells correlates with reduction of tumorigenicity in nude mice [16]. Rad9 knockdown also suppresses growth of human lung adenocarcinoma cells A549 and PC3 [18]. It is likely that increased Rad9 expression is needed for proliferation of tumor cells by mechanisms such as getting beyond (tolerating) oncogene-induced replicative stress and enhancing DNA repair capability. However, mice with conditional deletion of Rad9 in skin keratinocytes are inherently susceptible to the development of skin tumors in response to treatment with the carcinogen 7,12-dimethylbenzanthracene (DMBA)[19]. Thus far, there has been no report addressing the function of Rad1 in carcinogenesis.

To determine whether Rad1 functions to maintain genomic stability and prevent tumor development, we generated Mrad1 mutant mice by gene targeting. Homozygous deletion of Mrad1 leads to embryonic lethality, but heterozygous animals have no overt defects compared to $\mathrm{Mrad1} 1^{+/+}$mice. Combined treatment with DMBA and TPA induced skin tumors significantly more frequently in $\mathrm{Mrad1}^{+/-}$mice than in $\mathrm{Mrad1} 1^{+/+}$controls, and also caused significantly more and larger skin tumors in the mutant. Mrad1 $1^{+/}$keratinocytes contained more double strand DNA breaks as well, suggesting that this gene is critical for genome stabilization in keratinocytes, and that it carries a function important for preventing tumor development.

\section{Results}

Mouse embryonic lethality caused by Mrad1 homozygous deletion

To obtain Mrad1-disrupted ES cells, we used a promoterless gene targeting strategy to delete the gene [20]. Mrad1 was disrupted by homologous recombination in ES cells using the targeting vector illustrated in Fig. 1A. This targeting construct contains a selectable neo gene. This gene, which lacked the start codon (ATG), was inserted between the third exon and third intron of Mrad1, deleting parts of the third exon and third intron. Homologous recombination of the targeting construct into mouse genomic Mrad1 was predicted to generate mutant cells that express a fusion protein containing the 77AA of the Mrad1 N-terminus and a full length neo protein, but lacking the rest of the Mrad1 protein (part of the third exon and the complete 4, 5 and 6 exons). We then targeted a $129 \mathrm{~Sv} / \mathrm{Ev}$ ES cell line obtained from Dr. Victor Lin's laboratory (Columbia University) and $\mathrm{Mrad1}^{+/-} \mathrm{ES}$ cell clones were obtained after transfection and challenge

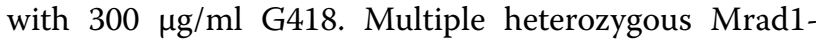
deleted clones were identified by Southern blot analysis
(Fig. 1B). A few were selected for PCR genotyping and confirmed to be Mrad1 heterozygous (Fig. 1C).

Mrad1 1/-ES cells were used to generate Mrad1 targeted mice (see Methods for details). Genotypes of the mice were analyzed by Southern blot hybridization (Fig. 1D) and PCR (Fig. 1E), and indicated that Mrad1 ${ }^{+/-}$animals were successfully generated. Mating between $\mathrm{Mrad1}^{+/-}$ mice only produced $\mathrm{Mrad1} 1^{+/+}$and $M r a d 1^{+/-}$offspring, providing evidence that Mrad1/- causes embryonic lethality. Mating between $\mathrm{Mrad1}^{+/-}$and $\mathrm{Mrad1}^{+/+}$mice generated almost equal numbers of $\mathrm{Mrad1}^{+/-}$and Mrad1 ${ }^{+/+}$pups (111:109), suggesting no effect of Mrad1 heterozygous mutation on embryonic survival. Mrad1/and wild type mice were maintained and monitored up to 1.5 years of age, and heterozygotes had no overt defects compared to wild type mice.

Mouse embryos at $7.5 \mathrm{dpc}$ with either the $M$ hus $1^{-/-}$or Mrad9-/- genotype are smaller than wild-type littermates, look morphologically abnormal, and eventually die during embryonic development $[21,22]$. To determine the embryonic morphology and the stage of embryonic lethality of Mrad1 homozygous mutants, embryos resulting from $\mathrm{Mrad1}^{+/-} \mathrm{X} \mathrm{Mrad1} 1^{+/}$crosses were retrieved at different stages of gestation. We examined embryos at $6.5 \mathrm{~d}, 7.5 \mathrm{~d}, 8.5 \mathrm{~d}, 10.5 \mathrm{~d}$ and $11.5 \mathrm{~d}$. Table 1 shows the numbers and genotypes of the embryos obtained. PCR was used to genotype DNA isolated from yolk sacs (Fig. 2A). Gross morphology of embryos at the different stages of development is presented in Fig. 2B. Mrad1/-, Mrad1+/+ and $\mathrm{Mrad1}^{+/}$embryos were identified at all stages analyzed. At E6.5, 23 of the 27 embryos are close in size and morphology except $2 \mathrm{Mrad1}^{-/-}, 2 \mathrm{Mrad1}^{+/+}$and $1 \mathrm{Mrad}^{+/}$ -embryos were relatively smaller but with normal morphology. Overall, deletion of Mrad1 does not impact on the size and gross morphology of the embryos by E6.5. At E7.5, however, there were many Mrad 1/- embryos significantly smaller than those with the Mrad1 ${ }^{+/-}$or $M r a d 1^{+/+}$ genotype. We retrieved three liters at E7.5, and the widths of the embryos were measured. The average width among the embryos with the same genotype was calculated, and then normalized to the average width of wild type embryos. Afterwards, the average widths of the embryos from the three liters were subjected to statistical analysis (T-test), and we found that the width of $M r a d 1^{-/}$embryos was statistically significantly smaller than that of $\mathrm{Mrad1}^{+/}$ + embryos ( $\mathrm{P}=0.016)$; the widths of $M r a d 1+/-$ and Mrad $1^{+/+}$embryos were statistically equal $(\mathrm{P}=0.11)$. At E8.5, Mrad1+/- and Mrad1+/+ embryos were further developed while Mrad1/- embryos still looked like the Mrad1-1 - embryos at E7.5 (data not shown). At E10.5 only amorphous material was found as Mrad1/- embryos (Fig. 2B), and at E11.5 $\mathrm{Mrad1}^{-/-}$embryos were completely resorbed. 


\section{A}

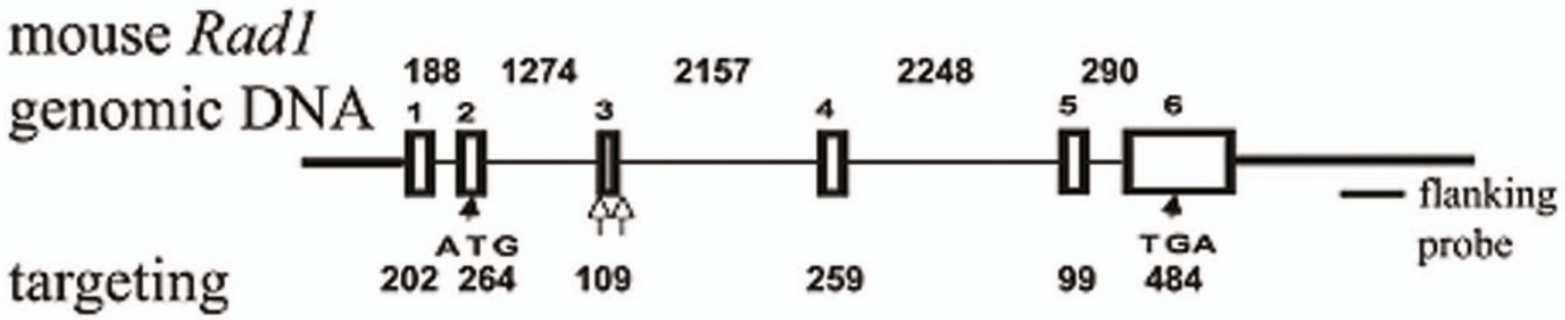

construct
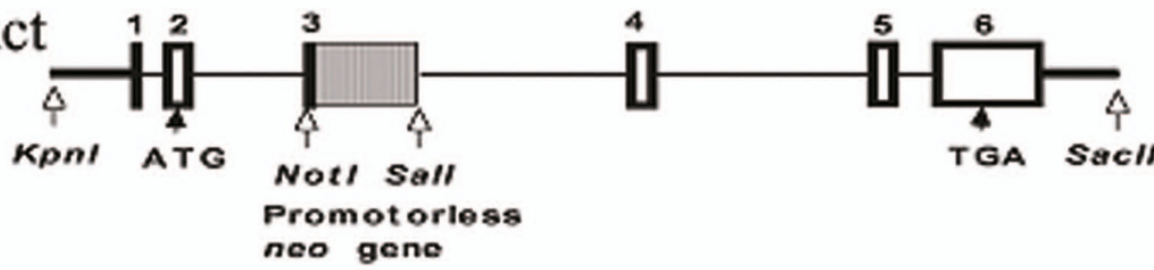

B
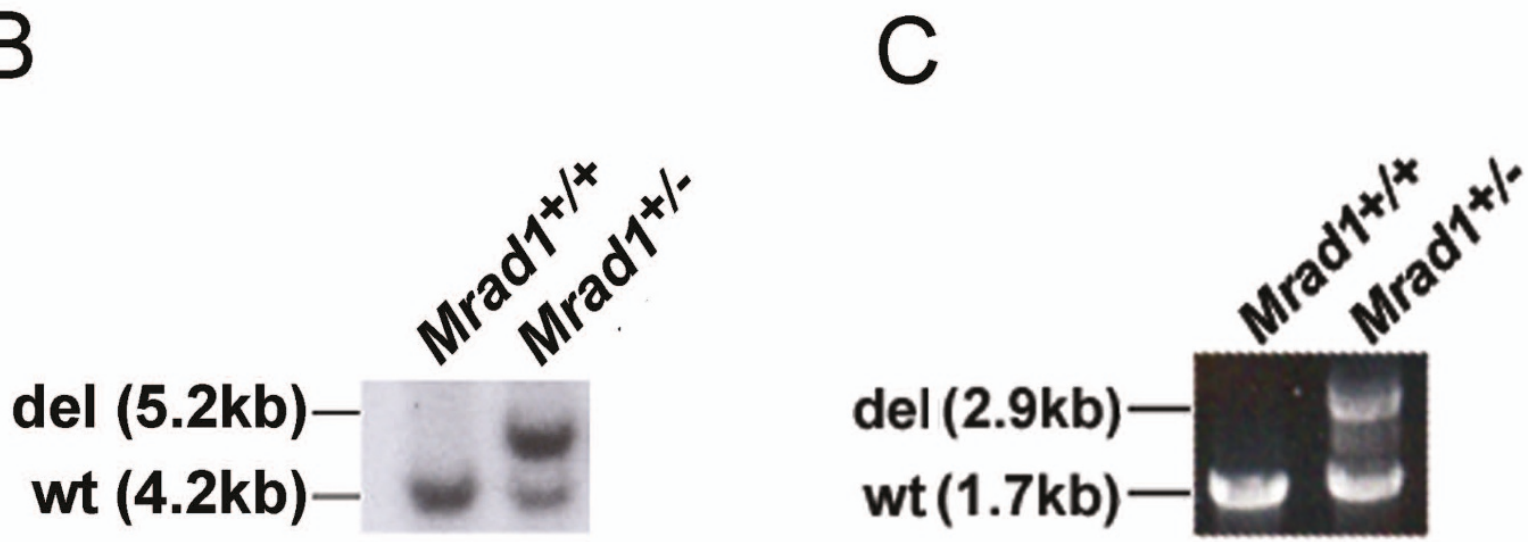

D
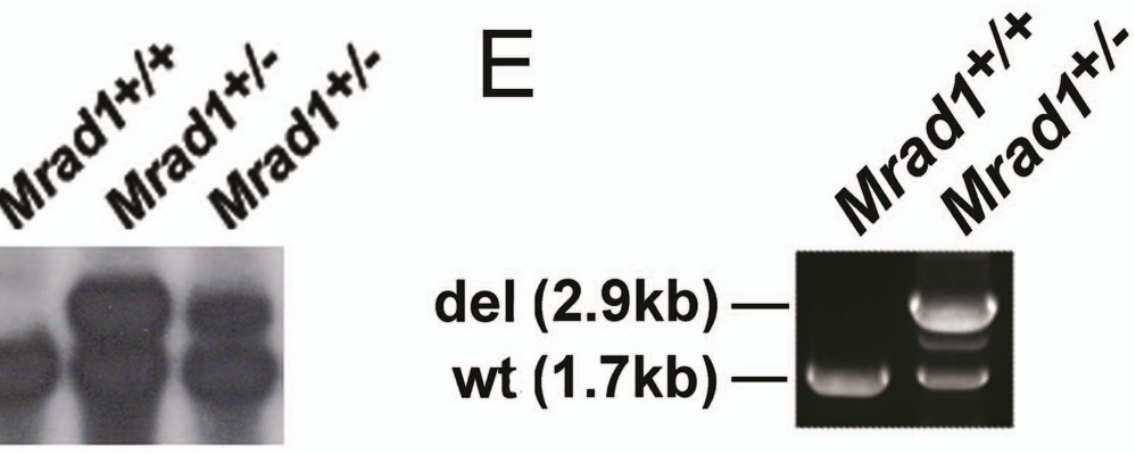

Figure 1 Targeted deletion of Mrad1. A, Top panel: Mrad1 genomic DNA; Bottom panel: targeting construct. White boxes: exons; Gray box: promotorless neo gene; black thin lines: introns; Black thick lines: DNA sequences outside of Mrad1 genomic DNA; Numbers above: lengths of introns in bp; Numbers below: lengths of exons in bp; White arrows: restriction enzyme cutting sites (targeting construct) and locations around the DNA sequence to be removed (genomic DNA); B, Southern blot analysis of the Mrad1 gene in mouse ES cells. Bands indicate wild-type and deleted Mrad1 allele. $C$, PCR to assess genotypes in mouse ES cells. Bands indicate wild-type and deleted Mrad1 allele. D, Southern blot analysis of the Mrad1 gene in mice. E, Mrad1 genotyping in mice using PCR. 

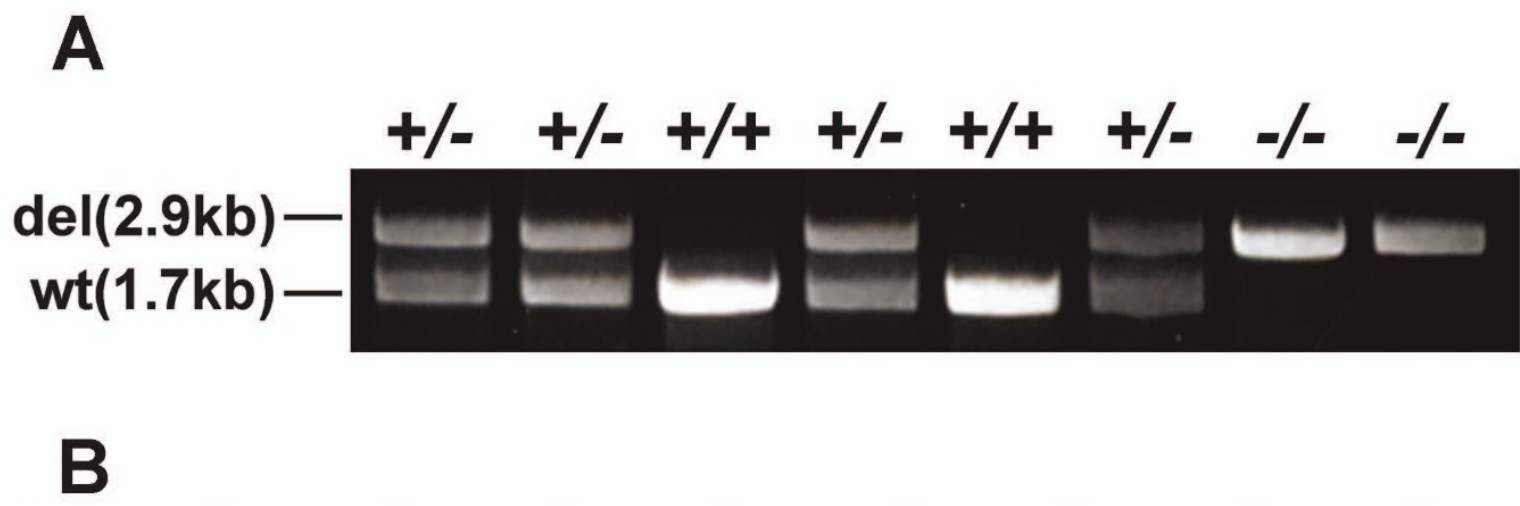

D6.5

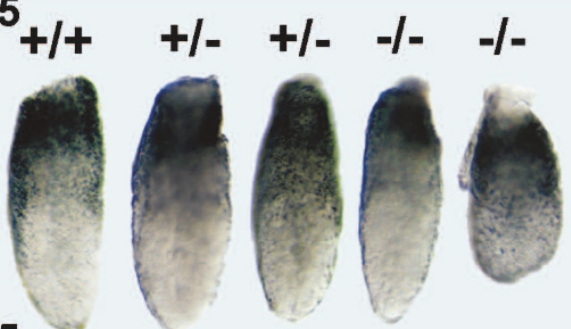

\section{D7.5}
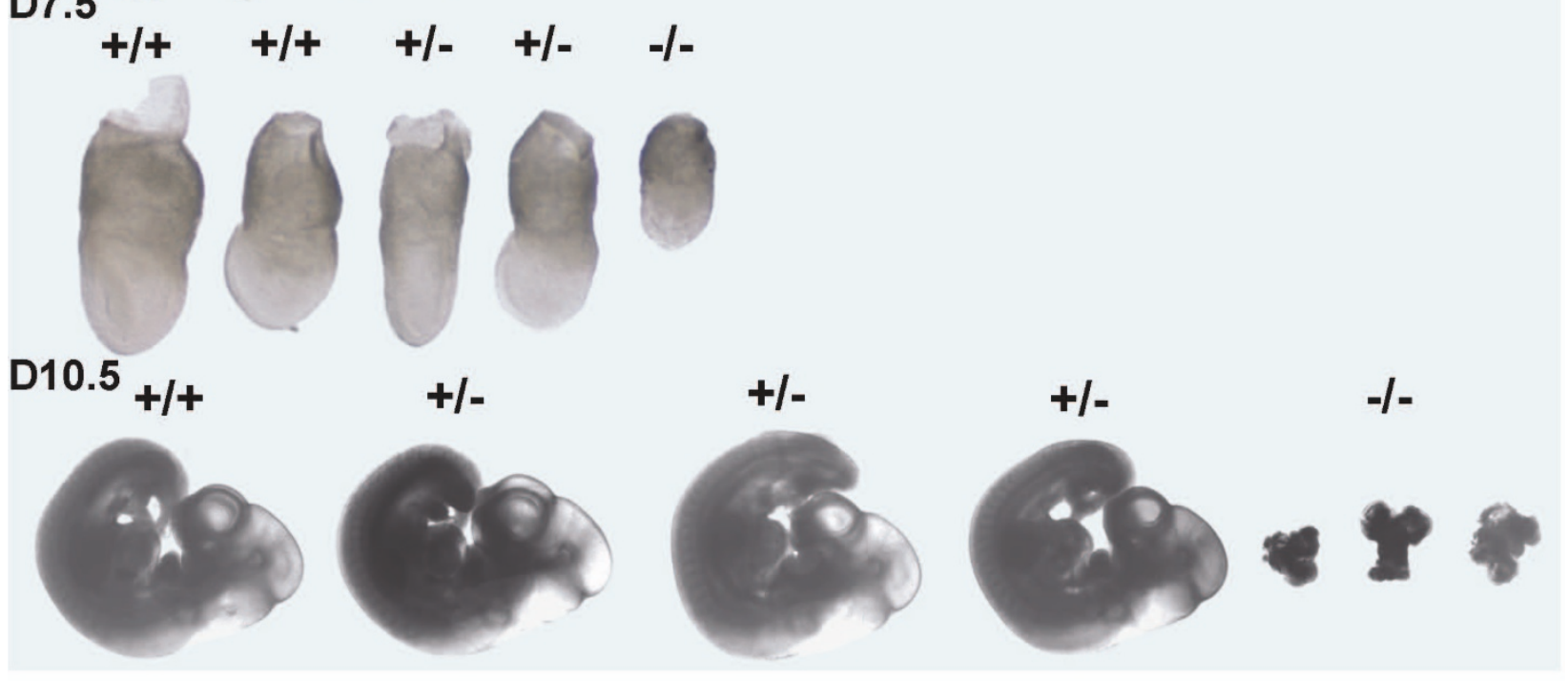

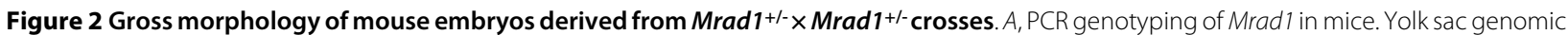
DNA was used as template. B, Representative gross morphology of Mrad 1 mouse embryos at E6.5, E7.5 and E10.5. A complete liter of embryos at each stage are presented. +/+, Mrad1+/+; +/-, Mrad1+/-; -/-, Mrad1 1/-

Taken together, as Mrad9 and Mhus1, Mrad1 is critical for embryonic development at or before E7.5.

\section{Mrad1 deletion enhances the incidence of mouse skin tumor development}

To determine if Mrad1 is important for tumorigenesis, the skin of mice with $M r a d 1^{+/+}$and $M r a d 1^{+/-}$genotypes was treated with DMBA plus TPA. A total of 38 mice were divided into 2 groups, each with the $\mathrm{Mrad1}^{+/+}$or Mrad1+/- genotype. The 2 groups were from 19 litters, each litter consisting of 2 mice with $\mathrm{Mrad1}^{+/+}$and Mrad1//- genotypes, and identical sex, either female (14 liters) or male (5 liters). Under this setting, Log-Rank Test in the Kaplan-Meier PL method can be used for statistical analysis on the significance of differences of tumor development between two groups of animals [23]. DMBA was used to initiate skin tumorigenesis, and TPA was used to promote skin tumor growth. Mice were first painted with $15 \mu \mathrm{g}$ DMBA in $100 \mu \mathrm{l}$ acetone. One week after DMBA treatment, mice were painted with $2 \mu \mathrm{g}$ TPA in $100 \mu \mathrm{l}$ 
Table 1: Numbers of embryos with indicated genotype.

\begin{tabular}{cccc}
\hline Stage & Mrad1+/+ & Mrad1+/- & Mrad1-/- \\
\hline E6.5 & 8 & 10 & 9 \\
E7.5 & 5 & 12 & 4 \\
E8.5 & 6 & 17 & 5 \\
E10.5 & 2 & 5 & 6 \\
E11.5 & 5 & 1 & 3 (resorptions) \\
\hline
\end{tabular}

acetone twice a week (Monday and Thursday) for 17 weeks. Only skin tumors larger than $1 \mathrm{~mm}$ were recorded. After 7 weeks of TPA treatment, rrad1 $^{+/-}$mice began to develop skin tumors in the treated area. It took 13 weeks of TPA treatment for the first $\mathrm{Mrad1} 1^{+/+}$mouse to develop skin tumors (Fig. 3A and 3B). At the $17^{\text {th }}$ week of TPA treatment, when the experiment ended, 14 Mrad1 $1^{+/-}$mice had skin tumors while only $7 \mathrm{Mrad1}^{+/+}$ mice, treated in the same fashion, developed skin tumors (Fig. 3B). Kaplan-Meier PL method [23] was used for comparison of the relative risk of tumor development induced by DMBA plus TPA between mice with different genotypes. The rate of tumor development in $\mathrm{Mrad1}^{+/-}$ mice was significantly higher than in $M r a d 1^{+/+}$mice ( $\mathrm{P}=$ 0.003, Log-Rank Test). Additionally, the average number of tumors in each of $\mathrm{Mrad1}^{+/-}$mice that developed tumors was significantly higher $(\mathrm{P}=0.010)$ than that in tumor-bearing $\mathrm{Mrad1}^{+/+}$mice (Fig. 3C). We also measured the size of tumors on mouse skin after 17 weeks of TPA treatment. Tumors larger than $6 \mathrm{~mm}$ in diameter only appeared in $\mathrm{Mrad1}^{+/-}$mouse skin (Fig. 3D; data not shown). We made skew analysis on the tumor size distribution and found that G1 values were 0.40528 and 1.84488 for the wild type and Mrad1 heterozygous mice, respectively, suggesting that Mrad1 heterozygous mice bore significantly larger tumors. Staining skin specimens with $\mathrm{H} \& \mathrm{E}$ or anti-keratin 14 indicated that the tumors were derived from keratinocytes and possessed characteristics of papillomas (Fig. 3E and 3F). All these data suggest that Mrad1 plays an important role in the prevention of skin papilloma development.

\section{Mrad1 deletion induces spontaneous double strand DNA breaks}

DNA repair and cell cycle control are two processes important for maintaining genomic integrity and preventing carcinogenesis $[1,2]$, thus we investigated these processes in keratinocytes bearing an Mrad1 deletion. First, we examined whether there is a significant change in the proliferation of the isolated keratinocytes resulting from the deletion of an allele of Mrad1. Cells were grown in defined Keratinocyte-SFM medium. Five hundred thousand cells, either $\mathrm{Mrad1} 1^{+/+}$or $\mathrm{Mrad1} 1^{+/-}$, were seeded into each well of 6 -well plates. The number of cells in each population dropped to nearly $40 \%$ of the seeded, original number $\left(2 \times 10^{5}\right.$ per well $)$ after the first 2 days of incubation. Subsequently, the total number of keratinocytes increased until day 12 when the experiment was terminated (Fig. 4A). There is a slight but significant difference in cell proliferation between $\mathrm{Mrad1}^{+/+}$and Mrad1 1/- keratinocytes (at Day $12, \mathrm{P}=0.03$ ). This result indicates that Mrad1 deletion affects the normal proliferation of cells although the influence is not dramatic.

The isolated keratinocytes were cultured in an incubator for 3 days before analysis of DNA damage. The neutral comet assay was used to detect DNA double-strand breaks (DSBs). There were significantly more DSBs in the incubated $\mathrm{Mrad1}^{+/-}$keratinocytes than in $\mathrm{Mrad1}^{+/+}$cells $(\mathrm{P}=0.004)$ (Fig. 4B). The phosphorylation of histone $\mathrm{H} 2 \mathrm{AX}(\gamma-\mathrm{H} 2 \mathrm{AX})$, a marker for the presence of DSBs, was also used to evaluate DSBs in $\mathrm{Mrad1}^{+/-}$and $\mathrm{Mrad1}^{+/+}$ keratinocytes in this study. Significantly more $M r a d 1^{+/-}$ keratinocytes contained $\gamma$-H2AX-positive foci than Mrad1 ${ }^{+/+}$cells, while significantly less $M r a d 1^{+/-}$keratinocytes contained no $\gamma-\mathrm{H} 2 \mathrm{AX}$ foci compared to $\mathrm{Mrad1} 1^{+/+}$ cells (Fig. 4C). Therefore, Mrad1 is critical for maintaining genomic integrity. We also studied the effects of Mrad1 deletion on apoptosis. The percentage of apoptotic cells among Mrad $1^{+/-}$keratinocytes is slightly higher than within the Mrad $1^{+/+}$cell population (Fig. 4D), but the difference is not statistically significant. We also examined the apoptosis levels induced by DMBA $(0.15 \mu \mathrm{g} / \mathrm{ml}$, $24 \mathrm{~h}$ ), and found that the apoptosis levels in both $\mathrm{Mrad}^{+1}$ - and $M r a d 1^{+/+}$keratinocytes were enhanced, but there were no statistically significant differences between the DMBA-induced apoptosis levels of $\mathrm{Mrad1}^{+/-}$and $\mathrm{Mrad1}^{+/}$ + cells, and between the mock-treated and DMBA-treated cells with either genotypes (Fig. 4D). The above results suggest that Mrad1 deletion in keratinocytes does not alter DMBA-induced apoptotic response in this experimental setting.

Flow cytometric analyses of PI-stained Mrad1 keratinocytes indicated that $M r a d 1^{+/-}$cells contained a slightly smaller G1 subpopulation and a slightly larger S subpop- 


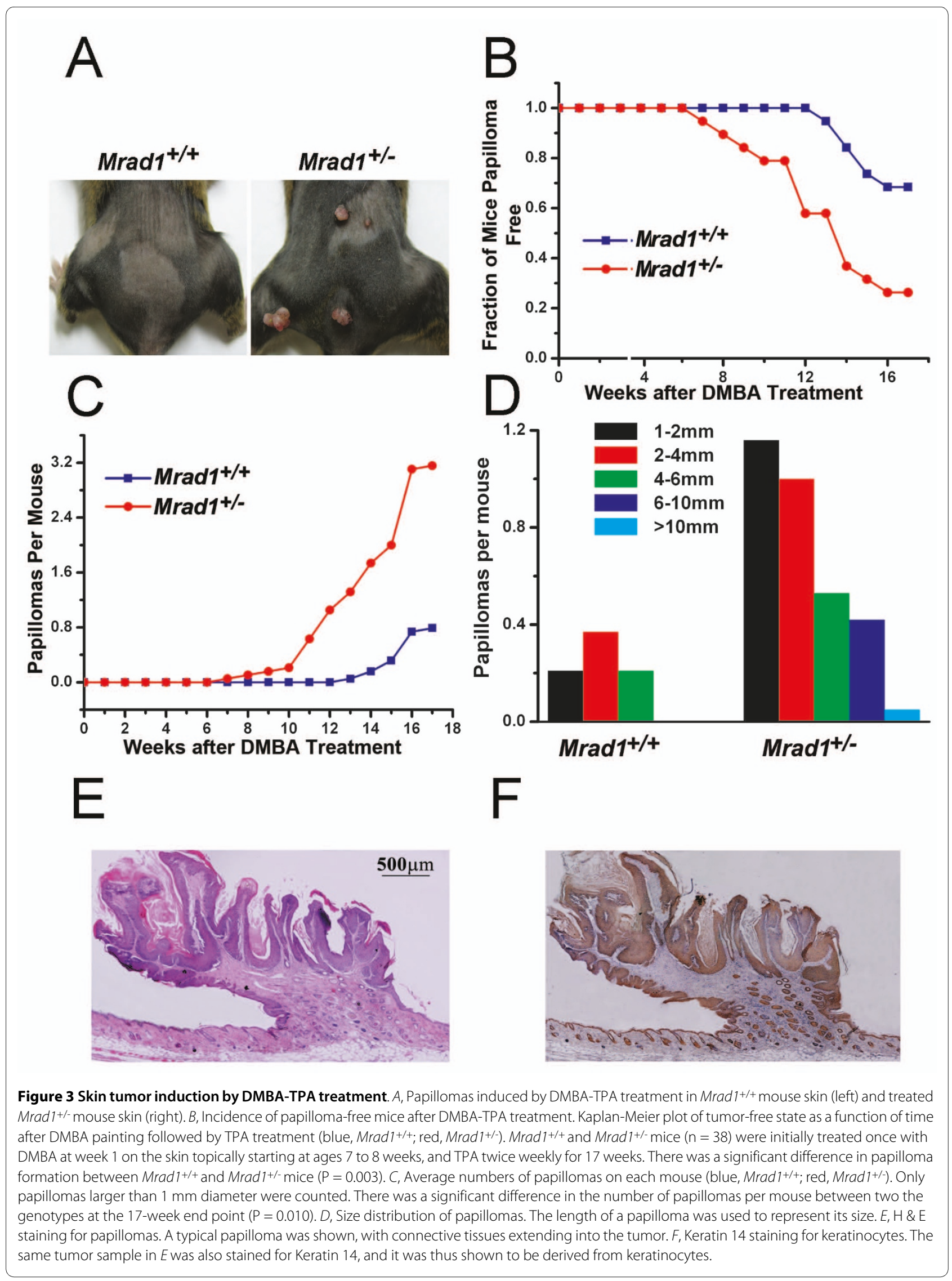


A

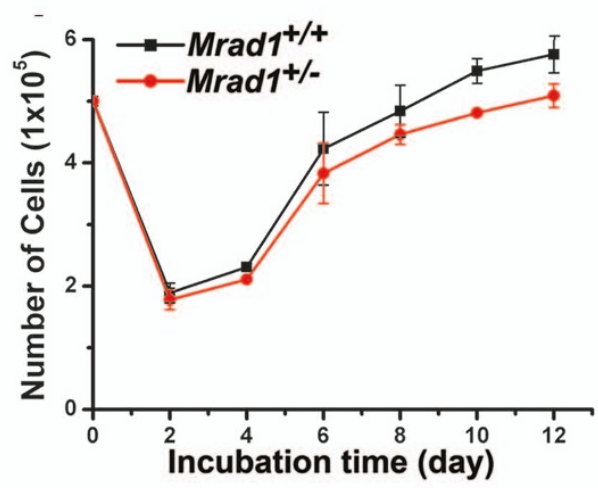

B

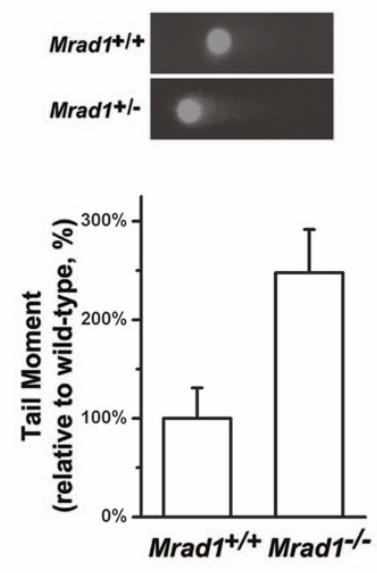

0

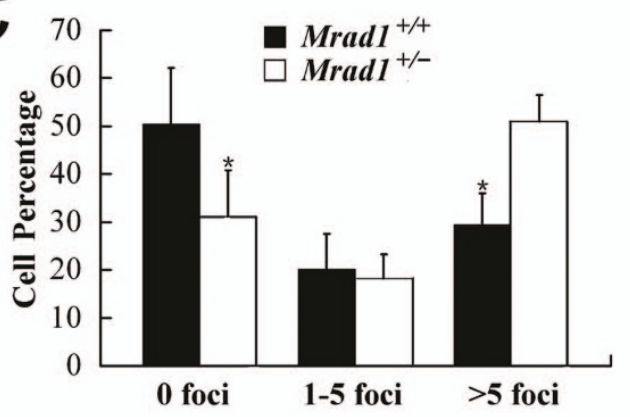

D
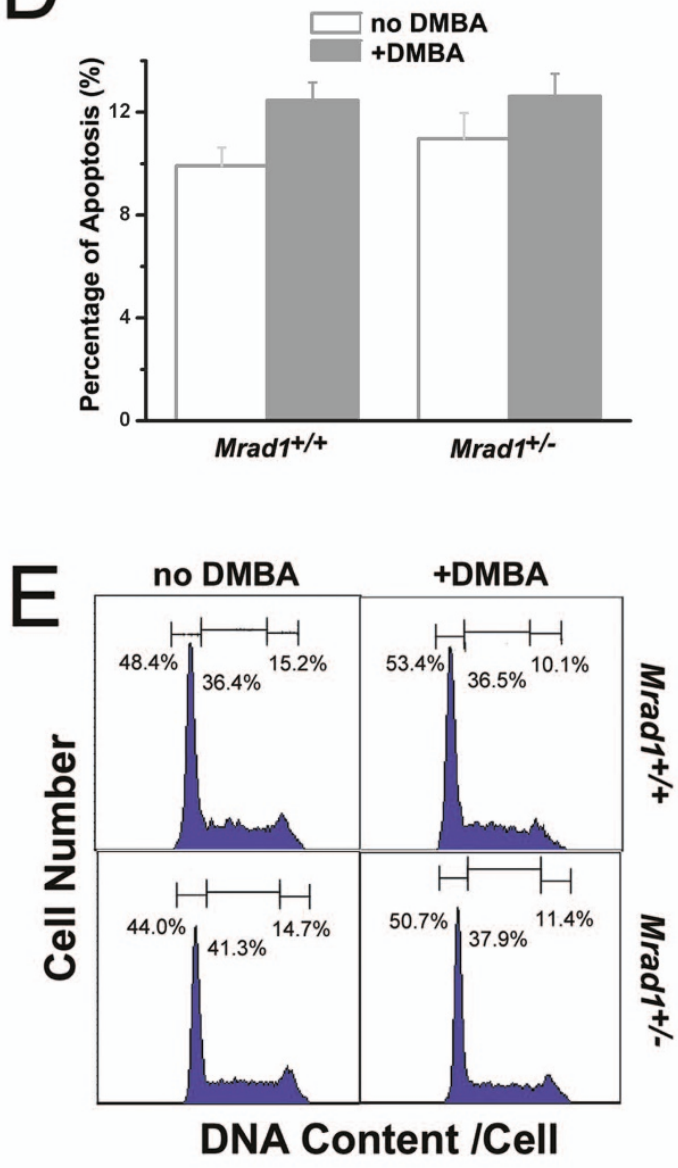

$\mathrm{F}$

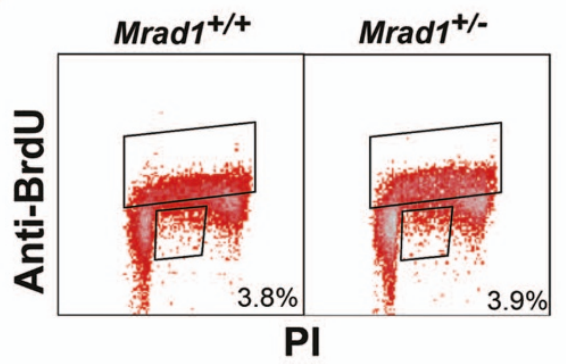

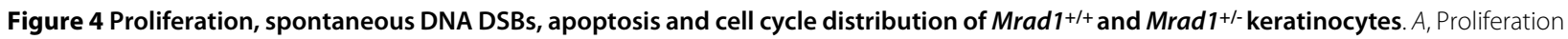
of skin keratinocytes. The average results were derived from three independent experiments. B, Spontaneous DNA double strand breaks detected with comet assay. The mean values were derived from three independent experiments, and each was the average of assays on 50 cells. $C$, Spontaneous DNA double strand breaks detected with $\mathrm{y}-\mathrm{H} 2 \mathrm{AX}$ labeling. Assessments were made by counting foci in at least 100 cells for every sample, and the result shown is the mean of triplicate samples for each genotype. Statistical analyses: $n=3, P=0.007$ for 0 foci, $P=0.42$ for $1-5$ foci and $P=0.0009$ for more 5 foci, D. Quantitative comparison of apoptosis between Mrad 1+/+ and Mrad 1+/-keratinocytes mock-treated and treated with DMBA for 24 h. The apoptotic levels were analyzed using Annexin V labeling. E, Comparison of cell cycle distribution of Mrad 1+/+ and Mrad 1+/-keratinocytes mock-treated and treated with DMBA. The numbers above each phase indicate the percentage of cells in that phase among the whole cell population. Mrad ${ }^{+/-}$ cells in G1 phase were not more than Mrad1 ${ }^{+/+}$cells in G1 phase. DMBA-TPA treatment slightly arrested cells in G1 phase. F, The cell cycle distributions of Mrad1+/+ and Mrad1+/- keratinocytes monitored with BrdUrd uptake. The cells were stained with both PI and anti-BrdUrd. The top box indicates BrdUrd-positive cells, and the number in the bottom right box is the percentage of BrdUrd-negative cells with late $S$ phase DNA content. 
ulation in the cell cycle than Mrad1+/+ cells (Fig. 4E). After incubation for $24 \mathrm{~h}$ in medium containing $0.15 \mu \mathrm{g} /$ ml DMBA, more cells with either Mrad1 phenotype were accumulated in $\mathrm{G} 1$ phase (Fig. 4E), indicating a functional G1 phase checkpoint control in both cell types. Measurement of BrdUrd uptake by replicative $S$ phase cells in combination with DNA content via PI staining in individual cells can reveal more information on cell cycle distribution. Therefore, we investigated cell cycle profiles in more detail by pulse labeling with BrdUrd and staining cells after 4 days of incubation. There is again no major difference in cell cycle distribution between $\mathrm{Mrad1}^{+/+}$and Mrad1 $1^{+/-}$keratinocytes. The number of BrdUrd-positive Mrad1 $1^{+/+}$cells in S phase is nearly the same as the number of $M r a d 1^{+/-}$cells (Fig 4F). Based on the above data, we conclude that Mrad1 deletion has only a slight effect on the distribution of cell cycle phase during in vitro incubation in both mock-treated and DMBA-treated conditions. This result is consistent with the finding that Mrad1 deletion only leads to a slight delay in proliferation of mouse skin keratinocytes.

\section{Expression of the cell cycle checkpoint genes p53, p21,} Mrad 9 and Mhus 1 in Mrad1 ${ }^{+/+}$and Mrad1 ${ }^{+/-}$keratinocytes In a previous study, we reported that deletion of either one or two alleles of Mrad9 induced expression of cell cycle checkpoint genes and dramatically reduced cell proliferation of keratinocytes in culture. The results herein show that Mrad1+/- keratinocytes have only a slightly lower proliferation rate than the $M r a d 1^{+/+}$controlcells (Fig. 4A). We therefore examined whether expression levels of $p 53$ and $p 21$ in $M r a d 1^{+/-}$keratinocytes are higher than in the related Mrad1+/+ cells. Indeed, heterozygous deletion of Mrad1 did not by itself alter expression of p21or $p 53$ in skin keratinocytes in culture (Fig. 5A). These results can explain why $M r a d 1^{+/-}$keratinocytes do not have significantly higher levels of apoptosis and only a slightly lower proliferation rate than those of the wild type keratinocyte control. We further investigated $p 21$ and p53 expression levels in keratinocytes treated with DMBA $(0.15 \mu \mathrm{g} / \mathrm{ml}, 24 \mathrm{~h})$ and found that the treatment induced expression most dramatically of $p 53$ but also somewhat $p 21$ in both $\mathrm{Mrad1}^{+/+}$and $\mathrm{Mrad1} 1^{+/-}$keratinocytes (Fig. 5A). The expression levels of Mrad9 and Mhus1 in keratinocytes withMrad1+/+ and $\mathrm{Mrad1}^{+/-}$genotypes were also examined by real-time PCR. The results show that Mrad9 and Mhus1 expression levels are not altered by one allele Mrad1 deletion (Fig. 5B), suggesting that there is no regulatory effect of Mrad1 on either Mrad9 or Mhus1 expression in mouse keratinocytes. Interestingly, Mrad1 expression levels in $\mathrm{Mrad1}^{+/-}$mouse skin tumors were higher than those in Mrad $1+/{ }^{+}$mouse skin tumors, but not statistically significantly (Fig. 5C).

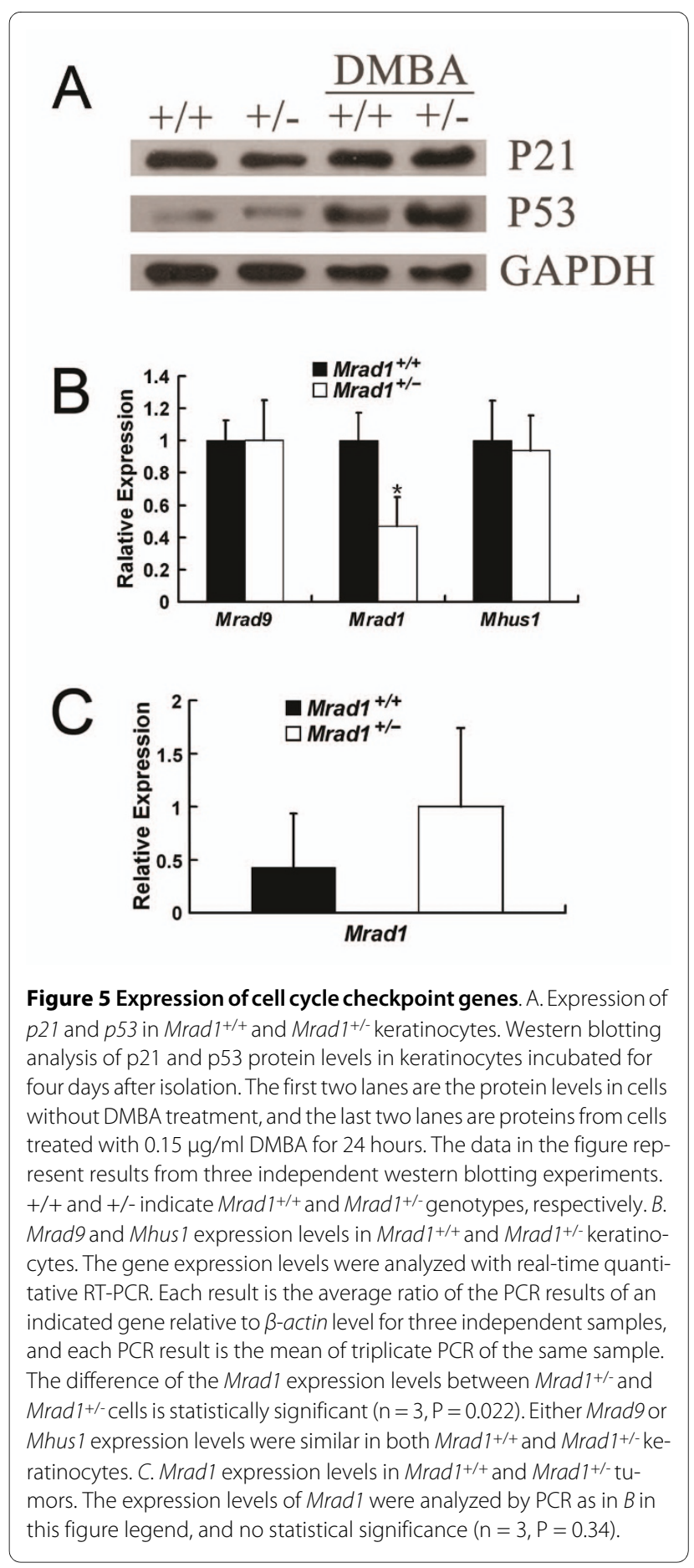

\section{Discussion}

Mouse Rad1 is homologous to Saccharomyces cerevisiae RAD17 (scRAD17; [24,25]), Schizosaccharomyces pombe rad1+ (sprad1+; [26-28]), Ustilago maydis REC1 [28,29] and human Rad1 [30-34]. In yeasts, $\operatorname{rad} 1$ is evolutionally conserved and a key component that mediates multiple cellular responses to DNA damage and cell cycle checkpoints [26,27,35-37]. After mouse and human Rad1 were 
transfected into corresponding mutant yeast cells, cell cycle checkpoint is restored. However, other functions of this gene in mammals are not well established. In this report, we examined whether Mrad1 prevents tumor formation and the mechanisms involved, using keratinocytes of mice with deletion of one Mrad1 allele because of the lethality caused by a Mrad1 homozygous null (Fig. 1). We showed that Mrad1 plays important roles in embryonic development and is required for preventing skin tumor formation induced by DMBA-TPA combinational treatment (Fig. 2 and Fig. 3). Thus we identify Mrad1 as an important genome caretaker or tumor suppressor for skin cancer.

Mrad9-/- and Mhus $^{-/-}$are critical for embryonic development at or before E7.5 [21,22]. We show in this study that homozygous deletion of Mrad1 also leads to embryonic lethality, and to slower growth and abnormal development at E7.5 (Fig. 2B). Therefore, the 9-1-1 (Rad9Hus1-Rad1) complex is likely essential for normal embryonic development.

Since $\mathrm{Mrad} 1^{+/-}$mice have no readily observable abnormalities up to 1.5 years of age, we examined whether combined treatment with DMBA and TPA on skin can reveal that heterozygous deletion of Mrad1 causes susceptibility to tumor development. As shown in Fig. 3A, the heterozygous Mrad1 deletion greatly enhanced tumor development. To understand the molecular mechanism behind the tumor-preventing function of Mrad1, we examined cell proliferation, DNA double strand breaks, apoptosis and cell cycle phase distribution of $\mathrm{Mrad1}^{+/+}$ and $M r a d 1^{+/-}$keratinocytes. Our results indicate that heterozygous deletion of Mrad1 did not increase the frequency of apoptosis (minor but not statistically significant increase), the expression of $p 53$ and $p 21$, and only slightly reduced cell proliferation, although the Mrad1 deletion did induce DNA double stand breaks (Fig. 4D, A, $B$ and 4C; Fig. 5A). In a previous study [19], we also demonstrated that heterozygous deletion of Mrad9 in keratinocytes led to spontaneous DNA double strand breaks. In addition, the heterozygous Mrad9 deletion induced apoptosis, high levels of $p 53$ and $p 21$ expression, and dramatically slowed down cell growth, which is different from what has been observed for the impact of Mrad1 deletion in keratinocytes. Therefore, Mrad1 and Mrad9 both prevent skin tumor development, but perhaps through different mechanisms and not exclusively via participation in the 9-1-1 complex. The 9-1-1 complex plays important roles in cell cycle checkpoint control and DNA damage repair which are important for genome stability, and thus Mrad1 and Mrad9 deletions may lead to skin tumors via loss of their genome caretaking function. Additional studies are needed to fully explain the mechanistic details and implications of these findings with respect to tumor prevention, and the impact on detection and treatment of cancer.

Among the three components in the 9-1-1 complex, human Rad9 expression has been most studied in human tumor tissues, partly due to available good anti-human Rad9 antibodies [13-16]. As mentioned above, the heterozygous deletion of Mrad9 induces apoptosis and dramatically reduces cell proliferation, the two features which act against tumor development and are not shared by the heterozygous deletion of Mrad1. Therefore, human cells with abnormal expression of human $\operatorname{Rad} 1$ or its malfunctioned mutations are more likely to survive and form tumors in patients. It would be interesting to examine Rad1 expression in human cancer tissues to find out the role of Rad1 in human tumor development.

Surprisingly, the Mrad1 expression level in Mrad1+/mice is twice that in $M r a d 1^{+/+}$mice although the difference is not statistically significant (Fig. 5C). However, the facts that the both null-Mrad9 and heterozygous Mrad1 deletion enhances susceptibility for skin tumor development, and that knockdown of highly expressed Rad9 in human prostate tumor cells correlates with reduction of tumorigenicity in nude mice [16] suggest the following models. At the very early stage, unrepaired DNA lesions enhances the opportunity for cellular genome to become more unstable and thus for the later-stage tumor development. A genome with extremely high instability does not support the cell's survival and proliferation. In the case of Mrad9 or Mrad1 deletion, mouse skin would become susceptible for tumor development owing to enhanced damaged cellular DNA, and in the case of human cancer, the highly expressed $\operatorname{Rad} 9$ would maintain the stability of the cancer cell genome to certain level so the cell could survive and proliferate. Obviously much more research work needs to be done to confirm the above models.

\section{Methods}

\section{Targeting vector construction}

A targeting vector was made to produce a deletion in Mrad1. We used the promoterless selection strategy to obtain a high efficiency of homologous gene targeting [20]. The targeting vector was constructed in three steps starting with pBluescript $\mathrm{SK}(+)$ vector. First, the 5'end fragment, a $1523 \mathrm{bp}$ Mrad 1 sequence between exon 2 and exon 3, was generated by PCR from $129 \mathrm{SvEv}$ mouse genomic DNA with primers:

5'-GTCTCAGGTTTTCACACATCTTCC-3' and 5'CTACGCGTCGACCTTCCTGAATGACAAATTC-

CTG-3' (Fig. 1A). The PCR product was cut with Kpn1 and Sal1, and subcloned into pBluescript SK(+). Second, the neo gene was amplified from pRc/CMV2 vector without the promoter and ATG using primers:

5'-CTACGCGTCGACATTGAACAAGATGGATTGCACGC-3' and 5'-AAGGAAAAAAGCGGCCGCAGA- 
CATGATAagataCATtGatgag-3'. Then, the PCR product was cut with Sal1 and Not1, and inserted in frame with Mrad1 into the plasmid constructed in the first step. Third, the 3'end fragment, 5591 bp long between intron 3 and intron 6 , was generated by PCR from $129 \mathrm{SvEv}$ mouse genomic DNA with primers:

5'-AAGGAAAAAAGCGGCCGCCTACTACAACTACTGCTACTAC-3' and 5'-TCCCCGCGGCACAGGACAGTACAGTAAGTCG-3'. The product was cut with SalI and SacII, and inserted into the vector constructed in the second step. This yielded the final targeting construct with the selectable neo gene, which was linearized with $K p n 1$ prior to transfection into ES cells.

\section{Growth of ES cells, gene targeting, and generation of Mrad1-deficient cells and mice}

ES cells derived from $129 \mathrm{SvEv}$ mice were cultured by established methods [38]. ES cells used to make gene-targeted mice were grown on feeder cells, electroporated with targeting vector linearized by $K p n 1$, and then grown in the presence of G418 at $300 \mu \mathrm{g} / \mathrm{ml}$. The G418-resistant clones were picked, expanded and subjected to Southern blot hybridization and PCR analyses to identify Mrad1+/targeted clones. Positive clones were injected into C57BL/ 6 blastocysts. Chimeric offspring were born and mated to C57BL/6 mice to confirm successful germ line transmission of the targeted Mrad1 allele. Genomic DNA from tails was analyzed by Southern blot hybridization and PCR analyses. Mrad1 heterozygous mutant mice were intercrossed and maintained.

\section{Southern blotting and PCR assays to assess genotypes}

For Southern blotting, genomic DNA was isolated from ES cells and tails of mice using published methods [22]. DNA was digested with HindIII, separated on a $0.7 \%$ agarose gel, then transferred to a nylon membrane, and hybridized to a ${ }^{32} \mathrm{P}$-labeled probe, which was generated by PCR using primers:

5'-GTGGCCTAGGTGGTTGCGTATCTGAAC-3' and 5'-GTCGGCTCCGAGAAGAAGGATGCTCC-3' in conjunction with mouse genomic DNA as template.

To genotype ES cells and mice by PCR, the reaction was performed using genomic DNA templates and the following primer pair:

5'-GTCTCAGGTTTTCACACATCTTCC-3' and 5'GCTTATATTCTAGAAACCTTCCTGTATG-3'. PCR conditions were $95^{\circ} \mathrm{C}$ for 5 min, followed by 35 cycles of $95^{\circ} \mathrm{C}$ for $30 \mathrm{~s}, 59^{\circ} \mathrm{C}$ for $30 \mathrm{~s}$, and $72^{\circ} \mathrm{C}$ for $3 \mathrm{~min}$, with a final extension at $72^{\circ} \mathrm{C}$ for $10 \mathrm{~min}$.

\section{Morphological analysis of mouse embryos}

Mouse embryos were obtained at several stages of gestation, including E6.5, E7.5, E8.5, E10.5, and E11.5. All dissections were performed in $1 \times$ PBS. Whole embryos were rinsed with $1 \times$ PBS. Pictures of whole embryos were taken while viewed by a Wild Heerbrugg dissecting microscope.

\section{Preparation and in vitro culture of keratinocytes}

Full-thickness skin removed from newborn (1-2 days old) mice was treated with $0.25 \%$ trypsin overnight at $4{ }^{\circ} \mathrm{C}$. The epidermis was peeled off from the dermis and minced into pieces smaller than $1 \mathrm{~mm}$. They were placed into a sterile flask, then dispersed by stirring into single cells for 30-60 min, then suspended in Keratinocyte-SFM medium with supplements (Invitrogen). Cells were first incubated in dishes coated with collagen type $\mathrm{I}$ at $34^{\circ} \mathrm{C}$ in $5 \% \mathrm{CO}_{2}$ for $12 \mathrm{~h}$ to allow cells to attach to the bottom. Afterwards, unattached cells were removed by washing with PBS. Attached cells were further cultured in fresh medium, which was replaced every 2 days.

\section{Western blotting}

For preparing protein from epidermis, full-thickness skin removed from newborn mice was treated with $0.25 \%$ trypsin overnight at $4^{\circ} \mathrm{C}$. The epidermis was peeled off from the dermis and dispersed in lysis buffer. To prepare cell lysate, keratinocytes incubated for 3 days were either left untreated or treated for $24 \mathrm{~h}$ with $0.15 \mu \mathrm{g} / \mathrm{ml}$ DMBA (Sigma). Then, the cell lysate was prepared in $1 \times$ SDSsample buffer, to a final concentration of $10^{4} \mathrm{cells} / \mu \mathrm{L}$. Fifty $\mu \mathrm{g}$ of protein were resolved on a $10 \%$ SDS-PAGE gel, and proteins were transferred to a polyvinylidene difluoride membrane. The membrane was probed consecutively with primary and peroxidase-conjugated secondary antibodies. Primary and secondary antibodies used in this study are mouse anti-GAPDH (KangChen, China), mouse anti-p21 (Santa Cruz), mouse anti-p53 (Oncogene), peroxidase-conjugated anti-rabbit IgG (A9169, Sigma) and peroxidase-conjugated anti-mouse IgG (A9044, Sigma).

\section{DMBA-TPA induced skin tumor formation}

Mice (7-8 weeks old) were shaved on their backs 2 days before tumor induction. To induce tumors, the shaved dorsal skin of mice was treated topically with $15 \mu \mathrm{g}$ of DMBA (Sigma) in $100 \mu \mathrm{L}$ acetone once. After 1 week, each animal received subsequent topical treatments of 2 $\mu \mathrm{g}$ of TPA (Sigma) in $100 \mu \mathrm{L}$ acetone twice weekly for 17 weeks. Treated areas were examined weekly for the presence of tumors, which were scored positive if they reached at least $1 \mathrm{~mm}$ in diameter.

\section{Histologic analysis and Immunohistochemistry}

Dorsal skin samples and tumors were fixed in $4 \%$ paraformaldehyde at $4^{\circ} \mathrm{C}$ overnight, embedded in paraffin, and sectioned as $8-\mu \mathrm{m}$ slices. The sectioned tissues on slides were stained with $H \& E$ [39,40]. Immunohistochemical staining was carried out using a kit (Immu- 
noCruz Staining Systems, Beijing Zhongshan Golden Bridge Biotechnology). The endogenous peroxidase activity in the specimens was blocked by treatment with $0.3 \% \mathrm{H}_{2} \mathrm{O}_{2}$ and samples were then rinsed with PBS. The specimens were probed consecutively with primary antibodies against Keratin 14 (BAbCo), secondary antibody biotin-conjugated goat anti-rabbit IgG, and horseradish peroxidase-streptavidin complex, and then visualized by diaminobenzidine. Afterwards, sections were counterstained with hematoxylin.

\section{Proliferation assay}

Keratinocytes were isolated as described above and seeded into 6 -well plates $\left(5 \times 10^{5}\right.$ cells per well $)$ containing Keratinocyte-SFM medium with supplements. Cell numbers were determined every 2 days.

\section{Cell cycle analyses}

The cell cycle profiles of cells in different phases were determined using previously established methods [41]. Briefely, $1 \times 10^{7}$ keratinocytes were plated in each $10-\mathrm{cm}$ dish. After incubation for 3 days the cells were mocktreated or treated with $0.15 \mu \mathrm{g} / \mathrm{ml}$ DMBA (Sigma) for 24 $\mathrm{h}$, then processed and stained with propidium iodide (PI), and analyzed by a FACSCalibur cytometer (Becton Dickinson). To assess DNA synthesis, $10 \mu \mathrm{M}$ BrdUrd was added to medium and cells were pulse labeled for $40 \mathrm{~min}$. Cells were then processed, probed with FITC-conjugated anti-BrdUrd antibody (Becton Dickinson) and stained with PI. Flow cytometric analyses were performed on a FACSCalibur.

\section{Apoptosis assay}

Keratinocytes incubated for 4 days were mock-treated or treated for $24 \mathrm{~h}$ with $0.15 \mu \mathrm{g} / \mathrm{ml}$ DMBA, trypsinized for 10 min using $0.1 \%$ trypsin at $37^{\circ} \mathrm{C}$, washed twice with cold PBS, then resuspended in $1 \times$ binding buffer [10 $\mathrm{mmol} / \mathrm{L}$ HEPES ( $\mathrm{pH} 7.4$ ), $140 \mathrm{mmol} / \mathrm{L} \mathrm{NaCl}$, and 2.5 $\mathrm{mmol} / \mathrm{L} \mathrm{CaCl}_{2}$ ] at a concentration of $1 \times 10^{6}$ cells $/ \mathrm{mL}$. Then cells were stained with Annexin V-FITC (Jingmei Biotech) and PI for $15 \mathrm{~min}$ at room temperature before flow cytometric analysis.

\section{Neutral comet assay}

Keratinocytes were cultured in standard medium for 4 days. The comet assay was carried out according to the manufacturer's instructions (Trevigen). Briefly, cells at a concentration of $1 \times 10^{5} / \mathrm{mL}$ were mixed gently with premelted low-temperature-melting agarose at a volume ratio of 1 to $10(\mathrm{v} / \mathrm{v})$ and spread on glass slides. The slides were then submerged in precooled neutral lysis buffer at $4^{\circ} \mathrm{C}$ for $30 \mathrm{~min}$. After rinsing, the slides were equilibrated in Tris-borate EDTA solution, electrophoresed at $1.0 \mathrm{~V} /$ $\mathrm{cm}$ for $20 \mathrm{~min}$, and then stained with PI. Fluorescence images for at least 50 nuclei were captured using a Nikon microscope and analyzed by CASP-1.2.2 software (University of Wroclaw) for tail moment (i.e., the geometric mean of fluorescence on the tail from the nucleus).

\section{Statistical analysis}

All statistical analyses were performed using statistical software package SPSS Version 10.0. The Kaplan-Meier PL method [23] was used for comparison of the relative risks of tumor development induced by DMBA-TPA between the mice with the two different Mrad1 genotypes. We designed the tumor development experiment to meet a set of conditions so the Log-Rank Test in the Kaplan-Meier PL method could be used. The Student's t test was performed to determine statistical significance of the differences for the comet assay. Wilcoxon rank-sum test was used to compare the difference in tumor numbers between the two groups of mice having different Mrad1 genotypes. In all the above analyses, a P value of < 0.05 was considered statistically significant. Skewness was used to compare the difference of tumor size distributions between Mrad1 wild type and heterozygous mice.

\section{Immunofluorescence assay}

Keratinocytes grown on coverslips were fixed with $4 \%$ paraformaldehyde in PBS for $15 \mathrm{~min}$ at room temperature, washed in PBS twice, incubated in PBS containing $0.5 \%$ Triton-X100 for $15 \mathrm{~min}$ and in PBS containing 5\% BSA and $0.1 \%$ Triton-X100 for $1 \mathrm{hr}$, and washed in PBS once, followed by incubation with anti-phospho-H2AX (Upstate) primary antibody (1:100 dilution) in PBS containing 5\% BSA and $0.1 \%$ Triton-X100 for $1 \mathrm{hr}$ at room temperature. Afterwards, the coverslips were washed two times for 5 min each in PBS and incubated with Texas Red -conjugated anti-mouse antibody (1:100 dilution in PBS containing 5\% BSA and $0.1 \%$ Triton-X100) for $1 \mathrm{hr}$ at room temperature. Finally, the coverslips were counterstained with DAPI $(10 \mathrm{ng} / \mathrm{ml})$. The images were captured using a fluorescence microscope.

\section{Quantitative real-time RT-PCR}

Total RNA was isolated from mouse tumors (3 wild type and $3 \mathrm{Mrad} 1$ heterozygous tumors) or keratinocytes cultured for 4 days using the RNeasy Mini kit, as described by the manufacturer (QIAGEN). Two $\mu$ g total RNA were reverse transcribed in a $20 \mu \mathrm{L}$ reaction volume to form cDNA using the SuperScript First-Strand Synthesis System for RT-PCR (Invitrogen). Real-time PCR was performed using the StepOnePlus system(ABI) with SYBR Green I (Takara) to label amplified DNA. A standard curve method of quantification was used to calculate the expression of target genes relative to the housekeeping gene $\beta$-actin. Experiments were performed thrice. The 
following primer pairs were used for the PCR reactions: Mrad9, 5'-GCCTCTTACTATCCACTTCG-3' and 5'AGCCCTCATTGCCTCC-3'; Mrad1, 5'-GCCCTATTTCAGGTTGT-3' and 5'-TGCCCATCTTCATTT CT-3'; Mhus1, 5'-TCCCTGTCTTACCGTGTC-3' and 5'CTCCCTTTAGGTTTGCTT-3'; $\beta$-actin, 5'-GTAAAGA CCTCTATGCCAACA-3' and 5'-GGACTCATCGTACT CCTGCT-3'. We used the following PCR procedure: $94^{\circ} \mathrm{C}$ for $3 \mathrm{~min}$, then 40 cycles of $94^{\circ} \mathrm{C}$ for $15 \mathrm{~s}, 55^{\circ} \mathrm{C}$ for $20 \mathrm{~s}$, $72^{\circ} \mathrm{C}$ for $19 \mathrm{~s}$, and a final extension at $72^{\circ} \mathrm{C}$ for $3 \mathrm{~min}$.

\section{Competing interests}

The authors declare that they have no competing interests.

\section{Authors' contributions}

LH planned and performed DMBA/TPA study, the morphological analysis of mouse embryos, culture of keratinocytes in vitro, proliferation, cell cycle, apoptosis and all the statistical analysis, and prepare the draft version of the manuscript. ZH performed immunohistochemistry and western blot. YL carried out neutral comet assay. XW and $\mathrm{KMH}$ contributed to the isolation of mouse embryos. $\mathrm{HH}$ designed the study and contributed to the manuscript preparation, and specifically performed targeting vector construction, gene targeting, southern blot and PCR. HBL helped designed the experiments and revised the manuscript. All authors have read and approved the final manuscript.

\section{Acknowledgements}

Grant support: National Natural Science Foundation of China $30530180(\mathrm{HH})$, National Protein Project of Ministry of Science and Technology 2006CB910902 $(\mathrm{HH})$, Knowledge Innovation Program of Chinese Academy of Sciences KSCX2YW-R63(HH), NIH grants GM079107 (HBL) and CA130536 (HBL).

\section{Author Details}

${ }^{1}$ National Laboratory of Biomacromolecules, Institute of Biophysics, Chinese Academy of Sciences, 15 Road Datun, Beijing 100101, China, ${ }^{2}$ Center for Computational and Systems Biology, Institute of Biophysics, Chinese Academy of Sciences, Beijing 100101, China, ${ }^{3}$ Department of Genetics \& Development, Columbia University Medical Center, 1130 St Nicholas Avenue, Room 311B, New York, NY 10032, USA, ${ }^{4}$ Obstetrics \& Gynecology, Columbia University Medical Center, 1130 St Nicholas Avenue, Room 311B, New York, NY 10032, USA, 5The Institute for Human Nutrition, Columbia University Medical Center, 1130 St Nicholas Avenue, Room 311B, New York, NY 10032, USA, 6 Herbert Irving Comprehensive Cancer Center, Columbia University Medical Center, 1130 St Nicholas Avenue, Room 311B, New York, NY 10032, USA, 7Center for Radiological Research, Columbia University, College of Physicians and Surgeons, 630 W 168thSt, New York, NY 10032, USA and ${ }^{8}$ Department of Environmental Health Sciences, Columbia University, Mailman School of Public Health, 60 Haven Avenue, Suite B1, New York, NY 10032, USA

Received: 25 July 2009 Accepted: 24 March 2010

Published: 24 March 2010

\section{References}

1. Deng CX: BRCA1: cell cycle checkpoint, genetic instability, DNA damage response and cancer evolution. Nucleic Acids Res 2006, 34:1416-1426.

2. Houtgraaf JH, Versmissen J, Giessen WJ van der: A concise review of DNA damage checkpoints and repair in mammalian cells. Cardiovasc Revasc Med 2006, 7:165-172.

3. Lieberman HB: Rad9, an evolutionarily conserved gene with multiple functions for preserving genomic integrity. J Cell Biochem 2006, 97:690-697.

4. Parrilla-Castellar ER, Arlander SJ, Karnitz L: Dial 9-1-1 for DNA damage: the Rad9-Hus1-Rad1 (9-1-1) clamp complex. DNA Repair (Amst) 2004, 3:1009-1014.

5. Helt CE, Wang W, Keng PC, Bambara RA: Evidence that DNA damage detection machinery participates in DNA repair. Cell Cycle 2005, 4:529-532.
6. Pandita RK, Sharma GG, Laszlo A, Hopkins KM, Davey S, Chakhparonian M, Gupta A, Wellinger RJ, Zhang J, Powell SN, et al:: Mammalian Rad9 plays a role in telomere stability, S- and G2-phase-specific cell survival, and homologous recombinational repair. Mol Cell Biol 2006, 26:1850-1864.

7. Wang $X$, Hu $B$, Weiss RS, Wang $Y$ : The effect of Hus 1 on ionizing radiation sensitivity is associated with homologous recombination repair but is independent of nonhomologous end-joining. Oncogene 2006, 25:1980-1983.

8. He W, Zhao Y, Zhang C, An L, Hu Z, Liu Y, Han L, Bi L, Xie Z, Xue P, et al: Rad9 plays an important role in DNA mismatch repair through physical interaction with MLH1. Nucleic Acids Res 2008, 36:6406-6417.

9. Venclovas C, Thelen MP: Structure-based predictions of Rad1, Rad9, Hus 1 and Rad17 participation in sliding clamp and clamp-loading complexes. Nucleic Acids Res 2000, 28:2481-2493.

10. Burtelow MA, Roos-Mattjus PM, Rauen M, Babendure JR, Karnitz LM: Reconstitution and molecular analysis of the hRad9-hHus1-hRad1 (9-11) DNA damage responsive checkpoint complex. J Biol Chem 2001, 276:25903-25909.

11. Shiomi Y, Shinozaki A, Nakada D, Sugimoto K, Usukura J, Obuse C, Tsurimoto T: Clamp and clamp loader structures of the human checkpoint protein complexes, Rad9-1-1 and Rad17-RFC. Genes Cells 2002, 7:861-868

12. Zhang H, Zhu Z, Vidanes G, Mbangkollo D, Liu Y, Siede W: Characterization of DNA damage-stimulated self-interaction of Saccharomyces cerevisiae checkpoint protein Rad17p. J Biol Chem 2001, 276:26715-26723

13. Maniwa Y, Yoshimura M, Bermudez VP, Yuki T, Okada K, Kanomata N, Ohbayashi C, Hayashi Y, Hurwitz J, Okita Y: Accumulation of hRad9 protein in the nuclei of nonsmall cell lung carcinoma cells. Cancer 2005, 103:126-132.

14. Cheng CK, Chow LW, Loo WT, Chan TK, Chan V: The cell cycle checkpoint gene Rad 9 is a novel oncogene activated by 11 q13 amplification and DNA methylation in breast cancer. Cancer Res 2005, 65:8646-8654

15. Chan V, Khoo US, Wong MS, Lau K, Suen D, Li G, Kwong A, Chan TK: Localization of hRad9 in breast cancer. BMC Cancer 2008, 8:196.

16. Zhu A, Zhang CX, Lieberman HB: Rad9 has a functional role in human prostate carcinogenesis. Cancer Res 2008, 68:1267-1274.

17. de la Torre J, Gil-Moreno A, Garcia A, Rojo F, Xercavins J, Salido E, Freire R: Expression of DNA damage checkpoint protein Hus1 in epithelial ovarian tumors correlates with prognostic markers. Int J Gynecol Pathol 2008, 27:24-32.

18. Yuki T, Maniwa Y, Doi T, Okada K, Nishio W, Hayashi Y, Okita Y: DNA damage sensor protein hRad9, a novel molecular target for lung cancer treatment. Oncol Rep 2008, 20:1047-1052.

19. Hu Z, Liu Y, Zhang C, Zhao Y, He W, Han L, Yang L, Hopkins KM, Yang X, Lieberman HB, Hang H: Targeted deletion of Rad 9 in mouse skin keratinocytes enhances genotoxin-induced tumor development. Cancer Res 2008, 68:5552-5561.

20. Sedivy JM, Dutriaux A: Gene targeting and somatic cell genetics--a rebirth or a coming of age? Trends Genet 1999, 15:88-90.

21. Hopkins KM, Auerbach W, Wang XY, Hande MP, Hang H, Wolgemuth D Joyner AL, Lieberman HB: Deletion of mouse rad9 causes abnormal cellular responses to DNA damage, genomic instability, and embryonic lethality. Mol Cell Biol 2004, 24:7235-7248.

22. Weiss RS, Enoch T, Leder P: Inactivation of mouse Hus 1 results in genomic instability and impaired responses to genotoxic stress. Genes Dev 2000, 14:1886-1898.

23. LEE ETWJ: Statistical Methods for Survival Data Analysis 3rd edition. New York: John Wiley and Sons; 2003

24. Lydall $D$, Weinert $\mathrm{T}$ : Yeast checkpoint genes in DNA damage processing: implications for repair and arrest. Science 1995, 270:1488-1491.

25. Siede W, Nusspaumer G, Portillo V, Rodriguez R, Friedberg EC: Cloning and characterization of RAD17, a gene controlling cell cycle responses to DNA damage in Saccharomyces cerevisiae. Nucleic Acids Res 1996 24:1669-1675.

26. al-Khodairy F, Carr AM: DNA repair mutants defining G2 checkpoint pathways in Schizosaccharomyces pombe. Embo J 1992, 11:1343-1350.

27. Rowley R, Subramani S, Young PG: Checkpoint controls in Schizosaccharomyces pombe: rad1. EMBO J 1992, 11:1335-1342.

28. Long KE, Sunnerhagen P, Subramani S: The Schizosaccharomyces pombe rad1 gene consists of three exons and the CDNA sequence is 
partially homologous to the Ustilago maydis REC1 CDNA. Gene 1994, 148:155-159.

29. Thelen MP, Onel K, Holloman WK: The REC1 gene of Ustilago maydis involved in the cellular response to DNA damage encodes an exonuclease. J Biol Chem 1994, 269:747-754.

30. Bluyssen HA, van Os RI, Naus NC, Jaspers I, Hoeijmakers JH, de Klein A: A human and mouse homolog of the Schizosaccharomyces pombe rad1 + cell cycle checkpoint control gene. Genomics 1998, 54:331-337.

31. Freire R, Murguia JR, Tarsounas M, Lowndes NF, Moens PB, Jackson SP: Human and mouse homologs of Schizosaccharomyces pombe rad1(+) and Saccharomyces cerevisiae RAD17: linkage to checkpoint control and mammalian meiosis. Genes Dev 1998, 12:2560-2573.

32. Marathi UK, Dahlen M, Sunnerhagen $P$, Romero AV, Ramagli LS, Siciliano MJ, Li L, Legerski RJ: RAD1, a human structural homolog of the Schizosaccharomyces pombe RAD1 cell cycle checkpoint gene. Genomics 1998, 54:344-347.

33. Parker AE, Weyer I Van de, Laus MC, Oostveen I, Yon J, Verhasselt P, Luyten WH: A human homologue of the Schizosaccharomyces pombe rad1+ checkpoint gene encodes an exonuclease. J Biol Chem 1998, 273:18332-18339.

34. Udell CM, Lee SK, Davey S: HRAD1 and MRAD1 encode mammalian homologues of the fission yeast rad $1(+)$ cell cycle checkpoint control gene. Nucleic Acids Res 1998, 26:3971-3976.

35. Enoch T, Carr AM, Nurse P: Fission yeast genes involved in coupling mitosis to completion of DNA replication. Genes Dev 1992, 6:2035-2046.

36. Murray JM, Carr AM, Lehmann AR, Watts FZ: Cloning and characterisation of the rad9 DNA repair gene from Schizosaccharomyces pombe. Nucleic Acids Res 1991, 19:3525-3531.

37. Lieberman HB, Hopkins KM, Laverty M, Chu HM: Molecular cloning and analysis of Schizosaccharomyces pombe rad9, a gene involved in DNA repair and mutagenesis. Mol Gen Genet 1992, 232:367-376.

38. Matise MP, Auerbach W, Joyner AL: Gene targeting. A practical approah. In Joyner AL (Series Editor): Production of targeted embryonic stem cell clones 2nd edition. New York (NY): Oxford University Press; 2000:101-132.

39. Yang L, Mao C, Teng Y, Li W, Zhang J, Cheng X, Li X, Han X, Xia Z, Deng H, Yang $X$ : Targeted disruption of Smad4 in mouse epidermis results in failure of hair follicle cycling and formation of skin tumors. Cancer Res 2005, 65:8671-8678.

40. Suzuki A, Itami S, Ohishi M, Hamada K, Inoue T, Komazawa N, Senoo H, Sasaki T, Takeda J, Manabe M, et al.: Keratinocyte-specific Pten deficiency results in epidermal hyperplasia, accelerated hair follicle morphogenesis and tumor formation. Cancer Res 2003, 63:674-681.

41. Hang $\mathrm{H}$ : Analysis of the mammalian cell cycle by flow cytometry Totowa (NJ): Humana Press; 2004.

\section{doi: 10.1186/1476-4598-9-67}

Cite this article as: Han et al., Mouse Rad1 deletion enhances susceptibility for skin tumor development Molecular Cancer 2010, 9:67

\section{Submit your next manuscript to BioMed Central} and take full advantage of:

- Convenient online submission

- Thorough peer review

- No space constraints or color figure charges

- Immediate publication on acceptance

- Inclusion in PubMed, CAS, Scopus and Google Scholar

- Research which is freely available for redistribution

Submit your manuscript at www.biomedcentral.com/submit
C) Biomed Central 